\title{
Genetic susceptibility to arsenic-induced skin lesions and health effects: a review
}

\author{
Somnath Paul, Sangita Majumdar and Ashok K. Giri
}

\begin{abstract}
Arsenic toxicity in humans manifests several outcomes in humans, which include arsenic-induced genomic instability, DNA damage, impaired DNA repair, carcinogenesis, dermatological lesions and other health related problems. Of the 137 million individuals affected, nearly 26 million individuals are in the state of West Bengal, India. Studies have identified dermatological lesions like keratosis, basal cell carcinoma, Bowen's diseases, squamous cell carcinoma, etc., as key indicators of aggressive arsenic toxicity in humans. Although a large number of individuals are exposed to arsenic but only about 15 to $20 \%$ individuals showed arsenic induced skin lesions. This clearly indicates that genetic susceptibility plays an important role in arsenic susceptibility. Analyses of genetic susceptibility have been carried out to study the prevalence of single nucleotide polymorphisms (SNPs) in number of genes as they might be involved arsenic metabolism and detoxification. It has been observed that a number SNPs in these genes were significantly associated with arsenic induced skin lesions and other health effects. In the present review we try to coalesce the different observations and associations of SNPs with arsenic-induced toxicity, with special emphasis on the study population from West Bengal. We have adopted certain candidate gene approaches to evaluate the association of arsenic-induced toxic outcomes like skin lesions, conjunctival irritations, DNA damage, epimutagenesis, cancer, etc. This review shall be helpful in understanding the importance of genetic make-up of an individual towards evaluating the xenotoxic outcomes, like those in case of arsenic exposure.
\end{abstract}

Keywords: Arsenic, Toxicity, Single nucleotide polymorphism, Genetic susceptibility, Epimutagenesis, West Bengal

\section{Introduction}

A global concern, a potent carcinogen and toxic upon chronic exposure, arsenic-induced toxicity in humans is multi-pronged; having a varied spectrum of pathophysiological outcomes. Nearly 137 million individuals are affected by arsenic in nearly 70 nations all over the world that includes India, Bangladesh, Taiwan, Japan, Chile and parts of China and USA [1, 2]. Apart from geogenic outcomes [3]; industrial and commercial activities have also lead to spread of arsenic like those of "the Toruku Mine incidence" and "the Nakajo-Machi incidence" in Japan in the early twentieth century [4]. Some of the major toxic outcomes of arsenic in humans include oxidative DNA damage, dermatological lesions in form of keratosis, peripheral neuropathy, gastrointestinal inflammation and cancers of various types like skin, lungs, bladder, liver, etc. [5-9].

\footnotetext{
*Correspondence: akgiri15@yahoo.com

Molecular and Human Genetics Division, CSIR-Indian Institute of Chemical Biology, 4, Raja S. C. Mullick Road, Kolkata 700032, West Bengal, India
}

Several mechanisms of arsenic-induced toxicity have been proposed and researched all over the world. Of these, enhanced toxicity due to reactive oxygen species (ROS) have been evaluated by several studies which was associated with a plethora of toxic outcomes like arsenic-induced cytogenetic damage, inflammation and carcinogenesis [10-12]. This aggressively oxidizes several cellular components and has been well characterized upon arsenic exposure like oxidative DNA damage $[8,13]$. Among the most recent concepts of research, arsenic-induced epigenetic alterations have also been associated with several molecular outcomes of arsenic toxicity. Arsenic biotransformation and metabolism within the cells involves a cascade of enzymes that converts inorganic arsenic to it's methylated species, using S-Adenosyl Methionine (SAM) as a substrate. This depelete indigenous SAM pool within the cells leading to arsenicinduced global DNA hypomethylation, leading to carcinogenic outcomes by aberrant gene expressions within the cell [14]. It was reported that Myc. overexpression was associated upon arsenic-induced malignant transformation in 
nude mice [15]. MYC, has a strong association with hepatic and pulmonary cancer with relevant studies showing association with chronic arsenic exposure with liver cancer and lung cancers [16-18]. This may be mediated by arsenicinduced epigenetic alterations of Myc. expression. Also, Myc has the ability to recruit TIP60 (a histone acetyl transferase; HAT) to the chromatin [19]. HAT category of enzymes are important regulators of histone acetylation; responsible for "opening up" of the nucleosomes and increase the accessibility of the transcription factors. This facilitates the transcription, along with DNA hypomethylation. This "opening up" may also enhance accessibility of ROS; leading to an increased degree of oxidative DNA damage. A probable mechanism is elaborated in Fig. 1.

Genetic susceptibility has been one of main proponent of arsenic-induced toxicity. Several population surveys all over the world have associated single nucleotide polymorphism (SNP) with arsenic-induced carcinogenesis. Dermatological lesions in form of raindrop hypo-pigmentation, palmer and plantar keratosis, Bowen's disease as well as squamous cell carcinoma (SCC) and basal cell carcinoma (BCC) have been considered as hallmarks of arsenic-induced toxicity or arsenicosis [20-22]. Thus, several epidemiological studies have evaluated the association between the dermatological lesions and cancer upon chronic arsenic exposure all over the world. SNP analysis of 594 arsenic-induced dermatological cases found a significant association between arsenic metabolic pathway genes with risk of premalignant skin lesions [23]. Arsenic (III) methyltransferase (AS3MT) is one of the main mediators of arsenic biotransformation. SNP (Met287Thr) of AS3MT has been found to be associated significantly with arsenic-induced skin premalignant lesions [24]. This study was conducted in Mexico, where the participants were subjected to nearly $110 \mu \mathrm{g} / \mathrm{L}$ arsenic through drinking water. The present review is on similar SNP studies conducted in the state of West Bengal, India where nearly 26 million individuals are consuming arsenic through drinking, above the limit of $10 \mu \mathrm{g} / \mathrm{L}$ as prescribed by World Health Organization [25]. In the present review we shall elaborate on the association
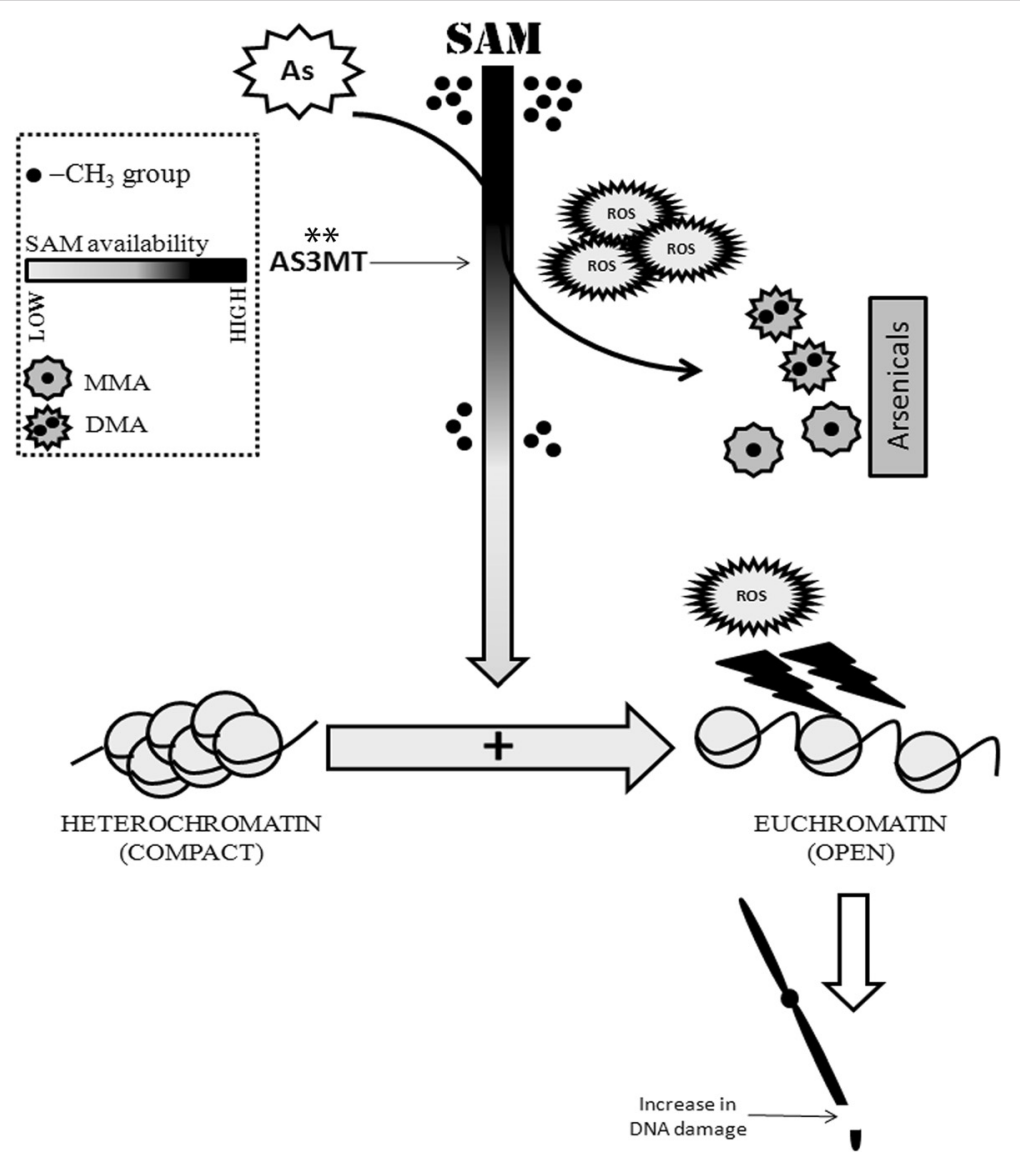

Fig. 1 Metabolic events upon arsenic consumption deplete the methylation pool within the cell. "**" indicates that AS3MT is a highly polymorphic enzyme. It's polymorphic profile can determine the degree of biotransformation of inorganic arsenic within the cellular system. This may induce indirectly the epigenetic susceptibility as discussed in section Polymorphism and arsenic-induced epigenetic susceptibility 
of genetic susceptibility in arsenic exposed population mainly from West Bengal with significant emphasis on dermatological lesions and cancers.

\section{Candidate genes responsible for arsenic toxicity in humans \\ Arsenic biotransformation pathway}

Arsenic biotransformation is a multistep process involving several enzymes. Some of the notable enzymes like AS3MT (methylated inorganic arsenic), purine nucleotide phosphorylase (PNP; acts as arsenic reductase), glutathione-S-transferase omega (GSTO; reduce arsenic metabolites), etc. have been associated with arsenic biotransformation within the body. Biotransformation of arsenic within the body leads to conversion of arsenic species as well as into organic intermediates for excretion of arsenic through urine. In a study involving more than 200 arsenic exposed samples from the arsenic affected districts of the state of West Bengal, elaborated that among $A S 3 M T, P N P$ and $G S T O(1 / 2)$, only exonic SNP of PNP showed a significant association in developing arsenic-induced dermatological lesions [26]. The three exonic SNP of PNP associated with arsenic-induced toxicity from this study mostly yielded a plausible condition of structural misnomer orientations of the proteins. For example the Gly51Ser alteration was predicted to alter the charge distribution within the region, which was important since the substitution was close to the arsenic binding site. It was suggested that the degree of arsenic transmethylation and conversion to MMA or DMA determines the susceptibility towards dermatological lesions [24]. As an explanation, the authors of these studies predicted the non-toxic values of DMA compared to MMA and hence a high MMA:DMA within the system predisposes an individual towards dermotological lesions $[23,27]$. A recent study elaborated that the rs9527 transcript variant of the 10q24.32 (associated with AS3MT) in individuals led to a lowering in the quantitative presence of DMA and had a higher risk in developing skin lesions [28]. Thus, genotype of an individual is a significant determinant towards the risk of developing arsenic-induced dermatological lesions.

\section{Inflammation and arsenic toxicity}

In vitro and in vivo studies have demonstrated that arsenic-induced toxic effects includes exaggerated expression of several pro-inflammatory as well as inflammatory factors like tumor necrosis factor alpha (TNF- $\alpha$ ) and interleukins (IL) like IL6, IL8 [7, 29, 30]. Two studies conducted by our group have found significant association between SNP of TNF- $\alpha$ (308 G > A), IL10 (3575 T > A) and NLRP2 (rs1043673) with arsenic-induced toxic outcomes in the population from West Bengal. In one study conducted with 207 arsenic exposed individuals with skin lesions and 190 arsenic exposed individuals without skin lesions, it was found that SNPs of TNF- $\alpha$ and IL1O had a higher association towards developing dermatological lesions [31]. Interestingly, since both the SNPs were located in the promoter regions of the corresponding genes, it was found that TNF- $\alpha$ A-allele showed a higher expression of the gene while in IL10 A-allele showed a lower production of IL10 in humans. Hence, genotype characteristic of a individual may dictate the course of inflammatory response upon arsenic-induced dermatological lesions. In another of our study, NLR family, pyrin domain containing 2 (NLRP2), a major component of the inflammasome complex imparted a higher risk of arsenic-induced dermatological lesions in individuals with the $\mathrm{C} / \mathrm{C}$ genotype [32]. The study also observed that coherent association of higher cytogenetic damage within arsenic exposed individuals having this NLRP2 C/C genotype (rs1043673). Earlier we had found a strong correlation between higher cytogenetic damage in arsenic exposed population with dermatological lesions [33].

\section{Polymorphic DNA repair genes}

DNA damage and subsequent repair equilibrium within the cell is an important perspective towards cell survival. ROS dependent DNA damage oversees several pathophysiological outcomes in humans including cancers, as elaborated by several authors [34, 35]. Studies have identified involvement of $\mathrm{p} 53$-dependent repair and cell regulatory pathways to play an active role in DNA damage recognition; bypassing which leads to development of oncogenic outcomes [36, 37]. Since arsenic consumption generates ROS, concomitant polymorphisms in several DNA repair pathway genes have been associated with increased cytogenetic damage upon arsenic exposure. Analysis of the SNP of ERCC2 (excision repair crosscomplementation group 2) codon 751 (A > C; rs13181), it was found that in case of arsenic-induced hyperkeratotic individuals, an over-representation of A/A genotype was present [38]. There was a decreased degree of DNA repair capacity exhibited by this polymorphic ERCC2 with A/A genotype [39]. This explains a higher cytogenetic damage observed in arsenic exposed individuals with ERCC2 A/A genotypes [38]. Evaluation of XRCC3 (X-Ray repair complementing defective repair in Chinese hamster cells 3 ), rs861539 implied that the distribution of $\mathrm{T} / \mathrm{T}$ or $\mathrm{C} / \mathrm{T}$ provides a beneficial protective role towards development of arsenic-induced skin lesions as well as DNA damage [40].

\section{Polymorphism of tumor suppressor gene- TP53}

The tumor suppressor protein TP53 or p53 plays a central role in mediating stress and DNA damage responses, leading to either growth arrest for DNA repairing or apoptosis [41]. The close association between codon 72 polymorphism of p53 with skin cancer has been 
reported by epidemiological survey [42]. In our study population, having chronic exposure to arsenic, a significant association been homozygous arginine at the codon 72 of p53 with arsenic induced keratosis [43]. Since, p53 dependent DNA repair is another mechanistic activity found in humans, it was also found that this polymorphism had a significant increase in accumulation of chromosomal aberrations (CA) among the keratotic individuals [44]. We conducted a study to compare the frequency distribution of chromosomal aberrations (\% aberrant cell and $\mathrm{CA} /$ cell) between the risk genotype (arginine homozygous) and the reference genotypes (arginine/proline heterozygous and proline homozygous combined) at p53 codon 72 locus with individuals without arsenic-induced skin lesions, individuals with keratosis and total population (two groups combined), and we found that the risk genotype containing homozygous arginine (R/R) had shown significantly higher chromosomal aberrations both in form of \% aberrant cell and CA/cell in two study groups individually.

\section{Polymorphism of glutathione S-transferase (GST) super family enzymes}

Glutathione S-transferases (GSTs) are a superfamily of enzymes, ubiquitously present and has multiple functionality like carcinogenesis $[45,46]$. The mechanistic modality of GST include conjugation of xenobiotic substances with glutathione, induction of other enzymes and proteins within the cellular micro-environment, etc. $[47,48]$. In our study population of West Bengal, we evaluated the null variants for GSTM1, GSTP1 and GSTT1, where we found a significant association of the GSTM1 null variants with arsenic exposed individuals without skin lesions, indicating of a protective role of GSTM1 null towards incidence of arsenic induced dermatological lesions [49]. This observation was interesting, especially with the fact that enzyme super-families having sequence homology more than $40 \%$, may have functional compensatory mechanism among the subgroups of the family $[50,51]$. In case of GSTM1, a recent study has evaluated the functional similarity between GSTM1 and GSTM2 in vitro, whereby GSTM2 showed an equivalent functional activity with GSTM1 [52]. Thus, although our earlier work observed the protective role of GSTM1 null towards developing arsenic induced skin lesions; the possibility of compensatory mechanism might be of significant importance in ultimately determining the genetic susceptibility towards arsenic induced skin lesions. Although it still remains a question that may be explored further, whether glutathione conjugation nature executed by GSTM2 is $100 \%$ same as that of GSTM1. Thus, this may explain the variability in "protection" upon GSTM1 null genotype.
Taking the arsenic exposed population in West Bengal, India, we hitherto try to put forward the major genes that may be considered as candidate genes to determine the extent of arsenic toxicity in humans, as briefed in Table 1, along with some similar works in other populations.

\section{Polymorphism and arsenic-induced epigenetic susceptibility}

Epimutagenesis is one of the modern terms, first coined by Holliday [53]. Presently, the term refers to the xenobiotic interactions of the cells, which in turn leads to alteration in the epigenomic profile of the cells. This may include alteration in the DNA methylation, histone post translational modifications and miRNA alterations. Arsenic exposure exhibits global DNA hypomethylation [14, 54]. Long interspersed nuclear element-1 (LINE-1) hypomethylation have been found positively associated with increase in arsenic-induced bladder cancer in women, in New Hampshire, USA [55]. Since SAM is an indigenous product of the cell, it's depletion by arsenic metabolism have been attributed to such epigenetic alterations. As mentioned earlier some genotypic variants of $A S 3 M T$ or it's splice variants has preferential tendency of either higher or lower MMA:DMA ratio [28, 56, 57]. Contemporary study has evaluated the possible association of hypomethylated blood DNA with increase in arsenic-induced skin lesions [58]. In humans, arsenic-induced epigenetic alterations is believed to be a primary contender for it's toxicity whereby both hypermethylated as well as hypomethylated promoters of tumor-suppressor as well as DNA repair genes have been reported from study population located in West Bengal $[59,60]$.

The involvement of differential methylation potential of AS3MT genotypic transcript variants warrants for further association studies to look into SNP of several other such epigenetically significant enzymes like DNMT3A (DNA methyltransferase 3A) at 448A > G has been associated with gastric cancer [61]; the homozygous variant of G/G at 201A > G of DNMT1 having a lower risk of developing breast cancer [62]. Although these two studies are not in conjunction to arsenic; the DNMT-class of enzymes are important determinants of the genomic methylation in all cells. When analyzed in Argentina, the arsenic exposed study population showed an association of DNMT1A SNP (rs16999593) with lowering in DMA\% [63]. Thus, when we are considering the gene and environment interactions as in case of arsenic exposure, such genotypic parameters should provide prognostic information about the fate of toxic outcomes in humans. Such seeded variability in methylation pattern also increases the probability to fall within the niche of epimutagenic events, whose 
Table 1 Summary of SNP analysis in candidate genes

\begin{tabular}{|c|c|c|c|c|c|c|c|}
\hline $\begin{array}{l}\text { Gene } \\
\text { (Reference) }^{b}\end{array}$ & Genotype; OR (95 \% Cl) & $p$-Value & Comments & Country (Reference) & Genotype; OR (95 \% Cl) & $p$-Value & Comments \\
\hline \multicolumn{4}{|l|}{ In West Bengal } & \multicolumn{4}{|l|}{ Outside West Bengal/India } \\
\hline ERCC2 [38] & $\begin{array}{l}\text { codon } 751 \mathrm{~A}>\mathrm{C}(\mathrm{A} / \mathrm{C}+\mathrm{C} / \mathrm{C})^{\mathrm{a}} \text { vs } \\
\mathrm{A} / \mathrm{A} ; 4.77(2.75-8.23)\end{array}$ & $<0.0001$ & $\begin{array}{l}\text { The A/A variant (Lys/Lys) of ERCC2 } \\
\text { demonstrated a suboptimal level of } \\
\text { DNA repair and were significantly } \\
\text { associated with arsenic-induced } \\
\text { hyperkeratosis. }\end{array}$ & China [65] & $\begin{array}{l}\text { codon } 751 \mathrm{~A}>\mathrm{C}(\mathrm{A} / \mathrm{C}+\mathrm{C} / \mathrm{C})^{\mathrm{a}} \text { vs } \\
\mathrm{A} / \mathrm{A} ; 2.36(1.35-4.14)\end{array}$ & $<0.01$ & $\begin{array}{l}\text { Lys demonstrated increased risk } \\
\text { of arsenic induced skin lesions } \\
\text { among the Chinese population. }\end{array}$ \\
\hline IL10 [31] & $\begin{array}{l}\text { promoter }-3575 T>A T / T^{\mathrm{a}} \text { vs } \\
(\mathrm{T} / \mathrm{A}+\mathrm{A} / \mathrm{A}) ; 2.03(1.26-3.28)\end{array}$ & $<0.01$ & $\begin{array}{l}\text { TNF-a and IL-10 variants were } \\
\text { associated with increased skin } \\
\text { lesions as well as overexpression } \\
\text { and underexpression of the factors } \\
\text { respectively. }\end{array}$ & Bangladesh [66] & rs3024496 A > G & $<0.05$ & $\begin{array}{l}\text { rs3024996 was significantly } \\
\text { associated with arsenic induced } \\
\text { skin lesions after multiple } \\
\text { comparison adjustments }\end{array}$ \\
\hline NLRP2 [32] & $\begin{array}{l}\text { codon } 1052(C>A) ; 0.67 \\
(0.46-0.97) C / C^{a} \text { vs }(C / A+A / A)\end{array}$ & $<0.05$ & $\begin{array}{l}\text { Presence of minor allele (A) lead to } \\
\text { prominent risk towards development } \\
\text { of arsenic-induced skin lesions. }\end{array}$ & No Other Studies yet found & & & \\
\hline TP53 [43] & $\begin{array}{l}\text { codon } 72(G>C) ; 2.086 \\
(1.318-3.299)\end{array}$ & $<0.001$ & $\begin{array}{l}\text { Arginine homozygous at codon } \\
72 \text { of p53 showed increased risk to } \\
\text { keratosis and higher chromosomal } \\
\text { aberration in arsenic-exposed } \\
\text { individuals. }\end{array}$ & Taiwan [67] & codon $72(G>C)$ & $<0.01$ & $\begin{array}{l}\text { Proline homozygous or } \\
\text { heterozygous showed a relative } \\
\text { higher risk in renal cell carcinoma, } \\
\text { upon arsenic exposure. }\end{array}$ \\
\hline \multirow[t]{3}{*}{ PNP [26] } & $\begin{array}{l}\text { codon } 20 \mathrm{C}>T \mathrm{C} / \mathrm{C}^{\mathrm{a}} \text { vs } \\
(\mathrm{C} / \mathrm{T}+\mathrm{T} / \mathrm{T}) ; 1.69(1.08-2.66)\end{array}$ & 0.02 & \multirow{3}{*}{$\begin{array}{l}\text { PNP variants are significantly } \\
\text { associated with arsenic induced } \\
\text { dermatological lesions }\end{array}$} & \multirow[t]{3}{*}{ Taiwan [68] } & \multirow[t]{3}{*}{$\begin{array}{l}\text { codon } 57 \mathrm{C}>\mathrm{T} C / \mathrm{C}^{\mathrm{a}} \text { vs } \\
(\mathrm{C} / \mathrm{T}+\mathrm{T} / \mathrm{T}) 1.50(1.03-2.18)\end{array}$} & \multirow[t]{3}{*}{$<0.05$} & \multirow{3}{*}{$\begin{array}{l}\text { PNP SNP results in a modified } \\
\text { and significant risk of carotid } \\
\text { artherosclerosis along with either } \\
\text { of AS3MT or GSTO1 SNP. }\end{array}$} \\
\hline & $\begin{array}{l}\text { codon } 51 \mathrm{G}>\mathrm{A} \mathrm{G} / \mathrm{G}^{\mathrm{a}} \text { vs } \\
(\mathrm{G} / \mathrm{A}+\mathrm{A} / \mathrm{A}) ; 1.66(1.04-2.64)\end{array}$ & 0.04 & & & & & \\
\hline & $\begin{array}{l}\text { codon } 57 C>T C / C^{a} \text { vs } \\
(C / T+T / T) ; 1.67(1.05-2.66)\end{array}$ & 0.04 & & & & & \\
\hline TNF-a [31] & $\begin{array}{l}\text { promoter }-308 \mathrm{G}>A \mathrm{G} / \mathrm{G}^{\mathrm{a}} \text { vs } \\
(\mathrm{G} / \mathrm{A}+\mathrm{A} / \mathrm{A}) ; 3.04(1.78-5.21)\end{array}$ & $<0.001$ & $\begin{array}{l}\text { TNF-a and IL-10 variants were } \\
\text { associated with increased skin } \\
\text { lesions as well as overexpression } \\
\text { and underexpression of the factors } \\
\text { respectively. }\end{array}$ & Taiwan [69] & promoter $-308 \mathrm{G}>\mathrm{A}$ & $<0.05$ & $\begin{array}{l}\mathrm{G} / \mathrm{A}+\mathrm{G} / \mathrm{G} \text { (low iAs) had a higher } \\
\text { risk of urothelial carcinoma upon } \\
\text { arsenic exposure compared to } \\
\text { A/A (high iAs) group. OR: } 14.98 ; \\
95 \% \text { Cl: } 2.63-85.44 \text {. }\end{array}$ \\
\hline$X R C C 3[40]$ & $\begin{array}{l}\text { codon } 241 C>T(C / T+T / T)^{a} \text { vs } \\
C / C ; 0.45(0.30-0.67)\end{array}$ & $<0.0001$ & $\begin{array}{l}\text { T: Methionine allele showed } \\
\text { protective role against } \\
\text { dermatological lesions as } \\
\text { well as cytogenetic damage. }\end{array}$ & $\begin{array}{l}\text { Hungary, Romania, } \\
\text { Slovakia [70] }\end{array}$ & $\begin{array}{l}\text { codon } 241 C>T C / C^{a}: \\
1.00 C / T: 0.7(0.54-0.92) \\
\text { T/T:0.54 }(0.36-0.8)\end{array}$ & $<0.01$ & $\begin{array}{l}\text { Associated significantly basal cell } \\
\text { carcinoma. }\end{array}$ \\
\hline
\end{tabular}

a Referent Group

${ }^{\mathrm{b}}$ West Bengal, India Reference; Mean arsenic content in drinking water from West Bengal study population was in the range of 151.74-194.82 $\mu \mathrm{g} / \mathrm{L}$. The WHO recommendation for arsenic through drinking water is $10 \mu \mathrm{g} / \mathrm{L}$ 
variability can bring forth different degrees of diseased outcomes in arsenic exposed individuals [64].

\section{Conclusion}

Arsenic toxicity provides a spectrum of pathophysiological outcomes in humans. Since there is a prominent interaction of this xenobiotic factor with the genes, the genotypic features have been considered vividly to understand the fate of toxic outcomes. The genetic make-up of an individual is hereditary. Hence in West Bengal as well as in other parts of the world, the arsenic exposed population possess a varied degree of cytogenetic damage as well as other clinical symptoms like peripheral neuropathy, respiratory disorders, etc. Taking studies in West Bengal as a comprehensive paradigm of arsenic toxicity, we propose that the genotype of an individual provides the signature of toxic fate upon arsenic exposure in individuals.

\section{Competing interests}

The authors declare that they have no competing interest.

\section{Authors' contributions}

SP and SM conducted literature review. SP, SM and AKG analyzed the information, developed strategies and wrote the manuscript. SP and AKG prepared the figure and table. All authors read and approved the final manuscript.

\section{Acknowledgements}

The authors would like to acknowledge Indian Council of Medical Research (ICMR), India for providing SRF to S.P. The authors are thankful to CSIR for financial support for the work (Emeritus Project 21(0885)/12/EMR-II to A.K.G).

Received: 17 July 2015 Accepted: 30 September 2015

Published online: 01 November 2015

\section{References}

1. Mukherjee A, Sengupta MK, Hossain MA, Ahamed S, Das B, Nayak B, et al. Arsenic contamination in groundwater:a global perspective with emphasis on the Asian scenario. J Health Popul Nutr. 2006;24(2):142-63.

2. UNICEF. Position paper prepared by the Policy Advisory Unit in UNICEF's Division of Policy and Strategy. 2013; http://www.unicef.org/media/files/ Current_Issues_Paper_-_Arsenic_Contamination_in_Groundwater.pdf (Accessed: April, 2015).

3. Islam FS, Gault AG, Boothman C, Polya DA, Charnock JM, Chatterjee D, et al. Role of metal-reducing bacteria in arsenic release from Bengal delta sediments. Nature. 2004;430(6995):68-71.

4. Tsuda T, Ogawa T, Babazono A, Hamada H, Kanazawa S, Mino Y, et al. Historical cohort studies in three arsenic poisoning areas in Japan. Appl Organometallic Chem. 2004;6(4):333-41.

5. Ghosh P, Banerjee M, De Chaudhuri S, Chowdhury R, Das JK, Mukherjee A, et al. Comparison of health effects between individuals with and without skin lesions in the population exposed to arsenic through drinking water in West Bengal, India. J Expo Sci Environ Epidemiol. 2007;17(3):215-23.

6. Paul S, Das N, Bhattacharjee P, Banerjee M, Das JK, Sarma N, et al. Arsenicinduced toxicity and carcinogenicity:a two-wave cross-sectional study in arsenicosis individuals in West Bengal, India. J Expo Sci Environ Epidemiol. 2013;23(2):156-62.

7. Calatayud M, Gimeno-Alcañiz JV, Vélez D, Devesa V. Trivalent arsenic species induce changes in expression and levels of proinflammatory cytokines in intestinal epithelial cells. Toxicol Lett. 2014;224(1):40-6.

8. Kumar S, Yedjou CG, Tchounwou PB. Arsenic trioxide induces oxidative stress, DNA damage, and mitochondrial pathway of apoptosis in human leukemia (HL-60) cells. J Exp Clin Cancer Res. 2014;33:42.

9. Steinmaus C, Ferreccio C, Yuan Y, Acevedo J, González F, Perez L, et al. Elevated lung cancer in younger adults and low concentrations of arsenic in water. Am J Epidemiol. 2014;180(11):1082-7.
10. Hei TK, Filipic M. Role of oxidative damage in the genotoxicity of arsenic Free Radic Biol Med. 2004;37(5):574-81.

11. Banerjee M, Banerjee N, Ghosh P, Das JK, Basu S, Sarkar AK, et al. Evaluation of the serum catalase and myeloperoxidase activities in chronic arsenicexposed individuals and concomitant cytogenetic damage. Toxicol Appl Pharmacol. 2010;249(1):47-54

12. Li C, Xu J, Li F, Chaudhary SC, Weng Z, Wen J, et al. Unfolded protein response signaling and MAP kinase pathways underlie pathogenesis of arsenic-induced cutaneous inflammation. Cancer Prev Res (Phila). 2011:4(12):2101-9.

13. Ding W, Hudson LG, Liu KJ. Inorganic arsenic compounds cause oxidative damage to DNA and protein by inducing ROS and RNS generation in human keratinocytes. Mol Cell Biochem. 2005;279(1-2):105-12.

14. Zhao CQ, Young MR, Diwan BA, Coogan TP, Waalkes MP. Association of arsenic-induced malignant transformation with DNA hypomethylation and aberrant gene expression. Proc Natl Acad Sci U S A. 1997;94(20):10907-12.

15. Chen H, Liu J, Zhao CQ, Diwan BA, Merrick BA, Waalkes MP. Association of c-myc overexpression and hyperproliferation with arsenite-induced malignant transformation. Toxicol Appl Pharmacol. 2001;175(3):260-8.

16. Liaw J, Marshall G, Yuan Y, Ferreccio C, Steinmaus C, Smith AH. Increased childhood liver cancer mortality and arsenic in drinking water in northern Chile. Cancer Epidemiol Biomarkers Prev. 2008;17(8):1982-7.

17. Saksela K, Bergh J, Lehto VP, Nilsson K, Alitalo K. Amplification of the c-myc oncogene in a subpopulation of human small cell lung cancer. Cancer Res. 1985:45(4):1823-7.

18. Smith AH, Goycolea M, Haque R, Biggs ML. Marked increase in bladder and lung cancer mortality in a region of Northern Chile due to arsenic in drinking water. Am J Epidemiol. 1998;147(7):660-9.

19. Frank SR, Parisi T, Taubert S, Fernandez P, Fuchs M, Chan HM, et al. MYC recruits the TIP60 histone acetyltransferase complex to chromatin. EMBO Rep. 2003;4(6):575-80.

20. Ghosh P, Banerjee M, De Chaudhuri S, Das JK, Sarma N, Basu A, et al. Increased chromosome aberration frequencies in the Bowen's patients compared to non-cancerous skin lesions individuals exposed to arsenic. Mutat Res. 2007;632(1-2):104-10.

21. Yamaoka H, Ikoma N, Kato M, Akasaka E, Tamiya S, Matsuyama T, et al. Multiple Bowen's disease in a patient with a history of possible arsenic exposure:a case report. Tokai J Exp Clin Med. 2011;36(2):53-7.

22. Ghosh SK, Bandyopadhyay D, Bandyopadhyay SK, Debbarma K. Cutaneous malignant and premalignant conditions caused by chronic arsenicosis from contaminated ground water consumption:a profile of patients from eastern India. Skinmed. 2013;11(4):211-6.

23. Ahsan $H$, Chen $Y$, Kibriya MG, Slavkovich V, Parvez F, Jasmine F, et al. Arsenic metabolism, genetic susceptibility, and risk of premalignant skin lesions in Bangladesh. Cancer Epidemiol Biomarkers Prev. 2007;16(6):1270-8.

24. Valenzuela OL, Drobná Z, Hernández-Castellanos E, Sánchez-Peña LC, García-Vargas GG, Borja-Aburto VH, et al. Association of AS3MT polymorphisms and the risk of premalignant arsenic skin lesions. Toxicol Appl Pharmacol. 2009;239(2):200-7.

25. WHO, World Health Organization, Guidelines for Drinking Water Quality. Health Criteria and Other Supporting Information, vol. 2 (2). Geneva: World Health Organisation; 1996. p. 940-9.

26. De Chaudhuri S, Ghosh P, Sarma N, Majumdar P, Sau TJ, Basu S, et al. Genetic variants associated with arsenic susceptibility:study of purine nucleoside phosphorylase, arsenic (+3) methyltransferase, and glutathione S-transferase omega genes. Environ Health Perspect. 2008;116(4):501-5.

27. Li $X, L i B, X u Y$, Wang $Y$, Jin $Y$, Itoh T, et al. Arsenic methylation capacity and its correlation with skin lesions induced by contaminated drinking water consumption in residents of chronic arsenicosis area. Environ Toxicol. 2011;26(2):118-23.

28. Pierce BL, Kibriya MG, Tong L, Jasmine F, Argos M, Roy S, et al. Genomewide association study identifies chromosome 10q24.32 variants associated with arsenic metabolism and toxicity phenotypes in Bangladesh. PLoS Genet. 2012;8(2):e1002522.

29. Calatayud M, Gimeno-Alcañiz JV, Devesa V, Vélez D. Proinflammatory effect of trivalent arsenical species in a co-culture of Caco-2 cells and peripheral blood mononuclear cells. Arch Toxicol. 2015;89(4):555-64.

30. Das S, Santra A, Lahiri S, Guha Mazumder DN. Implications of oxidative stress and hepatic cytokine (TNF-alpha and $\mathrm{IL}-6$ ) response in the pathogenesis of hepatic collagenesis in chronic arsenic toxicity. Toxicol Appl Pharmacol. 2005;204(1):18-26. 
31. Banerjee N, Nandy S, Kearns JK, Bandyopadhyay AK, Das JK, Majumder P, et al. Polymorphisms in the TNF-a and IL10 gene promoters and risk of arsenic-induced skin lesions and other nondermatological health effects. Toxicol Sci. 2011;121(1):132-9.

32. Bhattacharjee P, Das N, Chatterjee D, Banerjee A, Das JK, Basu S, et al. Association of NALP2 polymorphism with arsenic induced skin lesions and other health effects. Mutat Res. 2013;755(1):1-5.

33. Basu A, Mahata J, Roy AK, Sarkar JN, Poddar G, Nandy AK, et al. Enhanced frequency of micronuclei in individuals exposed to arsenic through drinking water in West Bengal, India. Mutat Res. 2002;516(1-2):29-40.

34. Loft S, Poulsen HE. Cancer risk and oxidative DNA damage in man J Mol Med (Berl). 1996;74(6):297-312.

35. Valko M, Izakovic M, Mazur M, Rhodes CJ, Telser J. Role of oxygen radicals in DNA damage and cancer incidence. Mol Cell Biochem. 2004:266(1-2):37-56.

36. Gorgoulis VG, Vassiliou LV, Karakaidos P, Zacharatos P, Kotsinas A, Liloglou T, et al. Activation of the DNA damage checkpoint and genomic instability in human precancerous lesions. Nature. 2005;434(7035):907-13.

37. Halazonetis TD, Gorgoulis VG, Bartek J. An oncogene-induced DNA damage model for cancer development. Science. 2008:319(5868):1352-5.

38. Banerjee M, Sarkar J, Das JK, Mukherjee A, Sarkar AK, Mondal L, et al. Polymorphism in the ERCC2 codon 751 is associated with arsenic-induced premalignant hyperkeratosis and significant chromosome aberrations. Carcinogenesis. 2007:28(3):672-6.

39. Lunn RM, Helzlsouer KJ, Parshad R, Umbach DM, Harris EL, Sanford KK, et al. XPD polymorphisms:effects on DNA repair proficiency. Carcinogenesis. 2000;21(4):551-5

40. Kundu M, Ghosh P, Mitra S, Das JK, Sau TJ, Banerjee S, et al. Precancerous and non-cancer disease endpoints of chronic arsenic exposure:the level of chromosomal damage and XRCC3 T241M polymorphism. Mutat Res. 2011;706(1-2):7-12.

41. Sandoval M, Morales M, Tapia R, del Carmen AL, Sordo M, Ostrosky-Wegman P, et al. p53 response to arsenic exposure in epithelial cells:protein kinase B/Akt involvement. Toxicol Sci. 2007;99(1):126-40.

42. Chen YC, Xu L, Guo YL, Su HJ, Hsueh YM, Smith TJ, et al. Genetic polymorphism in p53 codon 72 and skin cancer in southwestern Taiwan J Environ Sci Health A Tox Hazard Subst Environ Eng. 2003:38(1):201-11.

43. De Chaudhuri S, Mahata J, Das JK, Mukherjee A, Ghosh P, Sau TJ, et al. Association of specific p53 polymorphisms with keratosis in individuals exposed to arsenic through drinking water in West Bengal, India. Mutat Res. 2006;601(1-2):102-12

44. De Chaudhuri S, Kundu M, Banerjee M, Das JK, Majumdar P, Basu S, et al Arsenic-induced health effects and genetic damage in keratotic individuals:involvement of p53 arginine variant and chromosomal aberrations in arsenic susceptibility. Mutat Res. 2008;659(1-2):118-25.

45. Strange RC, Spiteri MA, Ramachandran S, Fryer AA. Glutathione-S-transferase family of enzymes. Mutat Res. 2001;482(1-2):21-6.

46. Strange RC, Fryer AA. The glutathione S-transferases:influence of polymorphism on cancer susceptibility. IARC Sci Publ. 1999;148:231-49.

47. Ketterer B, Meyer DJ, Taylor JB, Pemble S, Coles B, Fraser G. GSTs and protection against oxidative stress. In:Hayes JD, Pickett CB, Mantle TJ, eds. Glutathione S-transferase and drug resistance. London: Taylor and Frances; 1990. p. 97-109.

48. Hayes JD, Pulford DJ. The glutathione S-transferase supergene family:regulation of GST and the contribution of the isoenzymes to cancer chemoprotection and drug resistance. Crit Rev Biochem Mol Biol. 1995;30(6):445-600.

49. Ghosh P, Basu A, Mahata J, Basu S, Sengupta M, Das JK, et al. Cytogenetic damage and genetic variants in the individuals susceptible to arsenicinduced cancer through drinking water. Int J Cancer. 2006;1 18(10):2470-8.

50. Orengo CA, Bray JE, Buchan DW, Harrison A, Lee D, Pearl FM, et al. The CATH protein family database:a resource for structural and functional annotation of genomes. Proteomics. 2002;2(1):11-21.

51. Tian W, Skolnick J. How well is enzyme function conserved as a function of pairwise sequence identity? J Mol Biol. 2003;333(4):863-82.

52. Bhattacharjee $P$, Paul S, Banerjee M, Patra D, Banerjee $P$, Ghoshal N, et al. Functional compensation of glutathione S-transferase M1 (GSTM1) null by another GST superfamily member, GSTM2. Sci Rep. 2013;3:2704.

53. Holliday R. Endogenous DNA, methylation and epimutagenesis. Mutat Res. 1998;422(1):97-100.

54. Chen H, Li S, Liu J, Diwan BA, Barrett JC, Waalkes MP. Chronic inorganic arsenic exposure induces hepatic global and individual gene hypomethylation:implications for arsenic hepatocarcinogenesis. Carcinogenesis. 2004;25(9):1779-86.
55. Wilhelm CS, Kelsey KT, Butler R, Plaza S, Gagne L, Zens MS, et al. Implications of LINE1 methylation for bladder cancer risk in women. Clin Cancer Res. 2010;16(5):1682-9.

56. Agusa T, Iwata H, Fujihara J, Kunito T, Takeshita H, Minh TB, et al. Genetic polymorphisms in AS3MT and arsenic metabolism in residents of the Red River Delta, Vietnam. Toxicol Appl Pharmacol. 2009:236(2):131-41.

57. Hernández A, Xamena N, Surrallés J, Sekaran C, Tokunaga H, Quinteros D, et al. Role of the Met(287)Thr polymorphism in the AS3MT gene on the metabolic arsenic profile. Mutat Res. 2008;637(1-2):80-92.

58. Pilsner JR, Liu X, Ahsan H, Ilievski V, Slavkovich V, Levy D, et al. Folate deficiency, hyperhomocysteinemia, low urinary creatinine, and hypomethylation of leukocyte DNA are risk factors for arsenic-induced skin lesions. Environ Health Perspect. 2009;117(2):254-60.

59. Banerjee N, Paul S, Sau TJ, Das JK, Bandyopadhyay A, Banerjee S, et al. Epigenetic modifications of DAPK and p16 genes contribute to arsenicinduced skin lesions and nondermatological health effects. Toxicol Sci. 2013;135(2):300-8

60. Paul S, Banerjee N, Chatterjee A, Sau TJ, Das JK, Mishra PK, et al. Arsenicinduced promoter hypomethylation and over-expression of ERCC2 reduces DNA repair capacity in humans by non-disjunction of the ERCC2-Cdk7 complex. Metallomics. 2014;6:864-73.

61. Fan H, Liu D, Qiu X, Qiao F, Wu Q, Su X, et al. A functional polymorphism in the DNA methyltransferase-3A promoter modifies the susceptibility in gastric cancer but not in esophageal carcinoma. BMC Med. 2010;8:12.

62. Kullmann K, Deryal M, Ong MF, Schmidt W, Mahlknecht U. DNMT1 genetic polymorphisms affect breast cancer risk in the central European Caucasian population. Clin Epigenetics. 2013;5(1):7.

63. Engström K, Vahter M, Mlakar SJ, Concha G, Nermell B, Raqib R, et al. Polymorphisms in arsenic(+III oxidation state) methyltransferase (AS3MT) predict gene expression of AS3MT as well as arsenic metabolism. Environ Health Perspect. 2011;119(2):182-8.

64. Paul S, Giri AK. Epimutagenesis:A prospective mechanism to remediate arsenic-induced toxicity. Environ Int. 2015:81:8-17.

65. Lin GF, Du H, Chen JG, Lu HC, Guo WC, Golka K, et al. Association of XPD/ ERCC2 G23591A and A35931C polymorphisms with skin lesion prevalence in a multiethnic, arseniasis-hyperendemic village exposed to indoor combustion of high arsenic coal. Arch Toxicol. 2010;84:17-24.

66. Seow WJ, Pan WC, Kile ML, Tong L, Baccarelli AA, Quamruzzaman Q, et al. A distinct and replicable variant of the squamous cell carcinoma gene inositol polyphosphate-5-phosphatase modifies the susceptibility of arsenicassociated skin lesions in Bangladesh. Cancer. 2015. doi:10.1002/cncr.29291. [Epub ahead of print]

67. Huang CY, Su CT, Chu JS, Huang SP, Pu YS, Yang HY, et al. The polymorphisms of P53 codon 72 and MDM2 SNP309 and renal cell carcinoma risk in a low arsenic exposure area. Toxicol Appl Pharmacol. 2011;257:349-55

68. Hsieh YC, Lien LM, Chung WT, Hsieh Fl, Hsieh PF, Wu MM, et al. Significantly increased risk of carotid atherosclerosis with arsenic exposure and polymorphisms in arsenic metabolism genes. Environ Res. 2011;111:804-10.

69. Wu CC, Huang YK, Chung CJ, Huang CY, Pu YS, Shiue HS, et al. Polymorphism of inflammatory genes and arsenic methylation capacity are associated with urothelial carcinoma. Toxicol Appl Pharmacol. 2013;272:30-6.

70. Thirumaran RK, Bermejo JL, Rudnai P, Gurzau E, Koppova K, Goessler W, et al. Single nucleotide polymorphisms in DNA repair genes and basal cell carcinoma of skin. Carcinogenesis. 2006;27:1676-81.

\section{Submit your next manuscript to BioMed Central and take full advantage of:}

- Convenient online submission

- Thorough peer review

- No space constraints or color figure charges

- Immediate publication on acceptance

- Inclusion in PubMed, CAS, Scopus and Google Scholar

- Research which is freely available for redistribution 